\title{
Immobilization of Candida antarctica B (CALB) in Silica Aerogel: Morphological Characteristics and Stability
}

\author{
Aline Matuella Moreira Ficanha ${ }^{1,2}{ }^{\mathbb{D}}$, Angela Antunes ${ }^{2 \mathbb{D}}$, Carolina Elisa Demaman Oro ${ }^{2} \mathbb{D}$, Rogério \\ Marcos Dallago ${ }^{2}$ (D), Marcelo Luis Mignoni $2, * \mathbb{D}$ \\ 1 Department of Engineering, Centro de Ensino Riograndense, CEP 99150000 Marau - RS, Brazil. \\ alinematuella@gmail.com (A.M.M.F.); \\ 2 Department of Food and Chemical Engineering, URI - Erechim, 1621, Sete de Setembro Av., Erechim - RS, 99709-910, \\ Brazil. nenaantunes@gmail.com (A.A.); carolinae.oro@hotmail.com (C.E.D.O.); dallago@uricer.edu.br (R.M.D.); \\ mignoni@uricer.edu.br (M.L.M.); \\ * Correspondence: mignoni@uricer.edu.br;
}

Scopus Author ID 57189615164

Received: 26.04.2020; Revised: 23.05.2020; Accepted: 25.05.2020; Published: 27.05.2020

\begin{abstract}
Enzymes have been extensively used due to their catalytic properties, and immobilization is a promising technique to enhance their catalytic activity and stability. Lipases are enzymes naturally efficient, can be employed for the production of many different molecules, and have a wide range of industrial applications thanks to their broad selectivity. The objective of the present study was to characterize the Candida antarctica B CALB immobilized obtained using the aerogel technique regarding the morphological characteristics of the aerogel silica and its stability. For this purpose, analyzes of XRD, adsorption-desorption isotherms, TGA, SEM, and stability (storage, operational, and thermal) were performed. The supports obtained have an amorphous structure and isotherm type IV. Regarding TGA, two distinct regions were obtained and studied. Aerogels showed an increase in thermal, storage, and operational stability in relation to the free enzyme and demonstrated between 8 and 12 cycles of reuse. The contribution of this work was to present the stability advantages of the immobilized CALB enzyme through the sol-gel technique.
\end{abstract}

Keywords: CALB; silica; aerogel; operational stability; storage stability; thermal stability.

(c) 2020 by the authors. This article is an open-access article distributed under the terms and conditions of the Creative Commons Attribution (CC BY) license (https://creativecommons.org/licenses/by/4.0/).

\section{Introduction}

In the biotechnological area, the application of enzymes as biocatalysts in several processes becomes an alternative to replace conventional methodologies [1,2]. Lipases are enzymes that have been used as biocatalysts for a variety of reactions, due to their high activity and selectivity [3-5]. Among the lipases from different sources, Candida antarctica B (CALB) is particularly interesting due to its ability to catalyze various reactions [6-11]. It is one of the most used biocatalysts in organic synthesis due to its resistance to organic solvents, tolerance in non-aqueous media, specificity, and selectivity [12-15].

Despite the advantages of its use as biocatalysts, its practical application has some restrictions, such as low thermal and operational stability, costs with product separation, and the impossibility of reuse $[16,17]$. A strategy to overcome these drawbacks and enhance their stability in different reaction media is the immobilization process [18-20]. The immobilization process consists of keeping the catalyst confined to physical support. In this way, it makes viable the recovery of the biocatalyst from the reaction medium and allows the use repeatedly 
or continuously [21]. In addition, it improves its stability and enables wider temperature and $\mathrm{pH}$ ranges [22, 23].

The choice of support and immobilization technique becomes an important step. The support must have thermal and microbiological resistance, thermal stability, and have characteristics compatible with that of the enzyme to be immobilized [24, 25]. Among the techniques, one of the most used for the immobilization of biomolecules and other chemical catalysts described in the literature is the sol-gel technique [26, 27].

The sol-gel process starts from a homogeneous solution with a precursor, solvent, and catalyst that, through hydrolysis and condensation reactions, gives rise to a colloidal solution called sol. By polycondensation reactions, the sol is transformed into an integrated, solid network with the liquid phase (solvents, catalysts) in the interstices, and this semi-solid threedimensional structure is called a gel [28-30]. This gel goes through two more processes: aging and drying.

Among the immobilization techniques, the behavior of the lipase immobilized by the solgel technique relies on the physical structure of the support, the chemical and physical properties of the lipase used and the drying method chosen, among them using desiccators (xerogel) [31] or gases in supercritical conditions, such as $\mathrm{CO}_{2}$ (aerogel) [32-34].

Within this context, the objective of the present study was to characterize the CALB immobilized obtained using the aerogel technique regarding the morphological characteristics of the aerogel silica and its stability.

\section{Materials and Methods}

\subsection{Materials.}

The commercial lipase from Candida antarctica (CALB) was obtained from Novozyme (Bagswaerd, Denmark). The chemicals used for the sol-gel synthesis were tetraethoxysilane (TEOS Sigma-Aldrich) as a silica precursor, ammonium hydroxide (Quimex), hydrobromic acid (Vetec) as a catalyst and distilled water. To determination of esterification activity were used: ethanol (Merck), acetone (Merck), and sodium hydroxide (Synth). The substrate used in the esterification reaction was oleic acid (Aldrich) and ethanol (Merck). Carbon Dioxide $\left(\mathrm{CO}_{2}\right)$ (White Martins) was used for the drying of the support to obtain aerogel as a solvent.

\subsection{Synthesis of silica and CALB lipase immobilization in aerogel.}

The Candida antarctica B lipase was immobilized by the sol-gel technique, with the use of tetraethylorthosilicate (TEOS) as a precursor of silica, according to a methodology previously established [35]. The drying of the immobilized enzyme in the sol-gel matrix was carried out as described by Ficanha et al. [34], using pressurized $\mathrm{CO}_{2}$ sub and supercritical conditions. The choice of pressure values ( 80 bar to 200 bar) and temperature $\left(25^{\circ} \mathrm{C}\right.$ to $55^{\circ} \mathrm{C}$ ) were made considering the value of the $\mathrm{CO}_{2}$ density in each temperature and pressure condition. In the present study, the best results obtained by Ficanha et al. [34] were chosen for characterization. 
2.3. Morphological characterization of aerogel silica.

2.3.1. X-ray diffraction analysis (XRD) and textural analysis.

Aerogels were characterized by X-ray diffraction (XRD) (Rigaku, Miniflex II, K $\alpha$ - 1,58 $\mathrm{Cu}$ ). The specific surface areas of aerogels synthesized with and without enzyme were determined using the BET method [36]. The volume and average pore diameter were calculated by the BJH method. For the analysis of the surface area, the samples were previously submitted to a heat treatment at $60{ }^{\circ} \mathrm{C}$ with reduced pressure for $12 \mathrm{~h}$. The analysis was performed at a constant temperature of $-196^{\circ} \mathrm{C}(77 \mathrm{~K})$.

\subsubsection{Thermogravimetric Analysis (TGA).}

Thermogravimetric analyzes were performed on aerogels samples with and without immobilized enzymes. The TGA curves were obtained by the DTG-60H equipment simultaneously with the DTA-TG Shimadzu and analyzed using the Thermogravimetric Analyzer software, based on the loss of mass as a function of temperature. The operating rate was the heating rate of $20^{\circ} \mathrm{C} / \mathrm{min}$, in the ambient temperature range up to $600{ }^{\circ} \mathrm{C}$ and nitrogen flow of $50 \mathrm{~mL} / \mathrm{min}$.

\subsubsection{Scanning electron microscopy (SEM).}

The scanning electron microscopy was performed in a scanning electron microscope JEOL/EO with a voltage of $20 \mathrm{kV}$ and magnifications of 500 and 1000 times. Each sample was attached to a double-sided tape on the top of an aluminum cylinder. The material was covered with a thin layer of gold by electro-vaporization.

\subsection{Analytical determinations.}

\subsubsection{Determination of esterification activity.}

The esterification activity of the immobilized enzyme was carried out by the synthesis reaction of oleic acid and ethanol (molar ratio 1:1), according to Ficanha et al. [34].

\subsubsection{Storage stability.}

Storage stability is an important parameter that must be evaluated since its study will allow determining for how long the immobilized biocatalyst can be stored and how much of its initial activity will be maintained throughout the storage period. The experiments were carried out at room temperature $\left(20^{\circ} \mathrm{C}-25^{\circ} \mathrm{C}\right)$ and refrigeration $\left(3{ }^{\circ} \mathrm{C}-5^{\circ} \mathrm{C}\right)$. The stability was monitored until reaching a loss of $50 \%$ of its initial esterification activity. The results were presented as a percentage of residual activity (RA), calculated by Equation 1.

$$
R A(\%)=\frac{E A_{i}}{E A_{0}} \times 100
$$

Where: $\mathrm{EA}_{\mathrm{i}}=$ esterification activity at time " $i$ "; EA $0=$ initial esterification activity. 


\subsubsection{Operational stability.}

The efficiency of the operational stability (reuse) of the lipase immobilized in situ in aerogel was determined using a defined amount of the immobilized in successive cycles of ethyl oleate synthesis. After each batch, the reaction medium (liquid phase) was removed, and the solid phase (immobilized aerogel) was maintained. After this step, a new solution of oleic acid and ethanol was added. The residual activity of each cycle was calculated by the ratio of esterification activity in cycle $n$ to the esterification activity in cycle 1 (initial activity).

\subsubsection{Thermal stability.}

The thermal stability of immobilized and free CALB lipases was determined by the Arrhenius method. From the data obtained during the thermal stability evaluation, the degradation kinetics was determined through the analysis of the reaction order.

For this, the experiment was carried out by incubating the enzymes at temperatures from $40{ }^{\circ} \mathrm{C}$ to $80{ }^{\circ} \mathrm{C}$. Samples were taken over the incubation time to perform the esterification activity and to determine the residual activity.

The thermal deactivation constant $\left(\mathrm{k}_{\mathrm{d}}\right)$ at each temperature was calculated according to the Arrhenius kinetic model, considering that the enzyme deactivation follows the first-order kinetics, according to Equation 2.

$$
A=A_{0} \exp \cdot\left(-k_{d} \cdot t\right)
$$

Where: $\mathrm{A}=$ final activity; $\mathrm{A}_{0}=$ initial activity; $\mathrm{t}=$ time.

From the thermal deactivation constants at each temperature, the half-life times $\left(t_{1 / 2}\right)$ (Equation 3) were obtained, which corresponds to the time necessary for the inactivation of $50 \%$ of the initial enzyme concentration to occur at the temperature tested.

$$
t_{1 / 2}=-\frac{\ln 0,5}{k_{d}}
$$

Where: $\mathrm{t}_{1 / 2}=$ half-life time; $\mathrm{k}_{\mathrm{d}}=$ deactivation constant.

\section{Results and Discussion}

\subsection{Morphological characterization.}

3.1.1. X-ray diffraction analysis (XRD) and textural analysis.

The characterization of the porosity of the silica aerogel, whether with or without enzymes, is an important factor as it helps to understand the results of the enzymatic activity. The X-ray diffractograms for the aerogel obtained with different drying conditions in the presence of the lipase are shown in Figure 1.

All aerogels with enzymes exhibit the same behavior in relation to their diffractograms, with no peaks that characterize crystalline materials, but halos in the region conceived between $15-30 \mathrm{o}(2 \theta)$, which characterize them as amorphous materials.

The amorphous structure of materials obtained by the sol-gel technique was described by Hench and Noguès [37], in which they report that the hydrolysis and condensation reactions 
of the silicon monomer in the presence of an acid catalyst $(\mathrm{HBr})$ act as a cross-linking agent with the formation of the amorphous structure $\mathrm{SiO}_{2}$, in which the three-dimensional lattice is formed around of the enzyme.

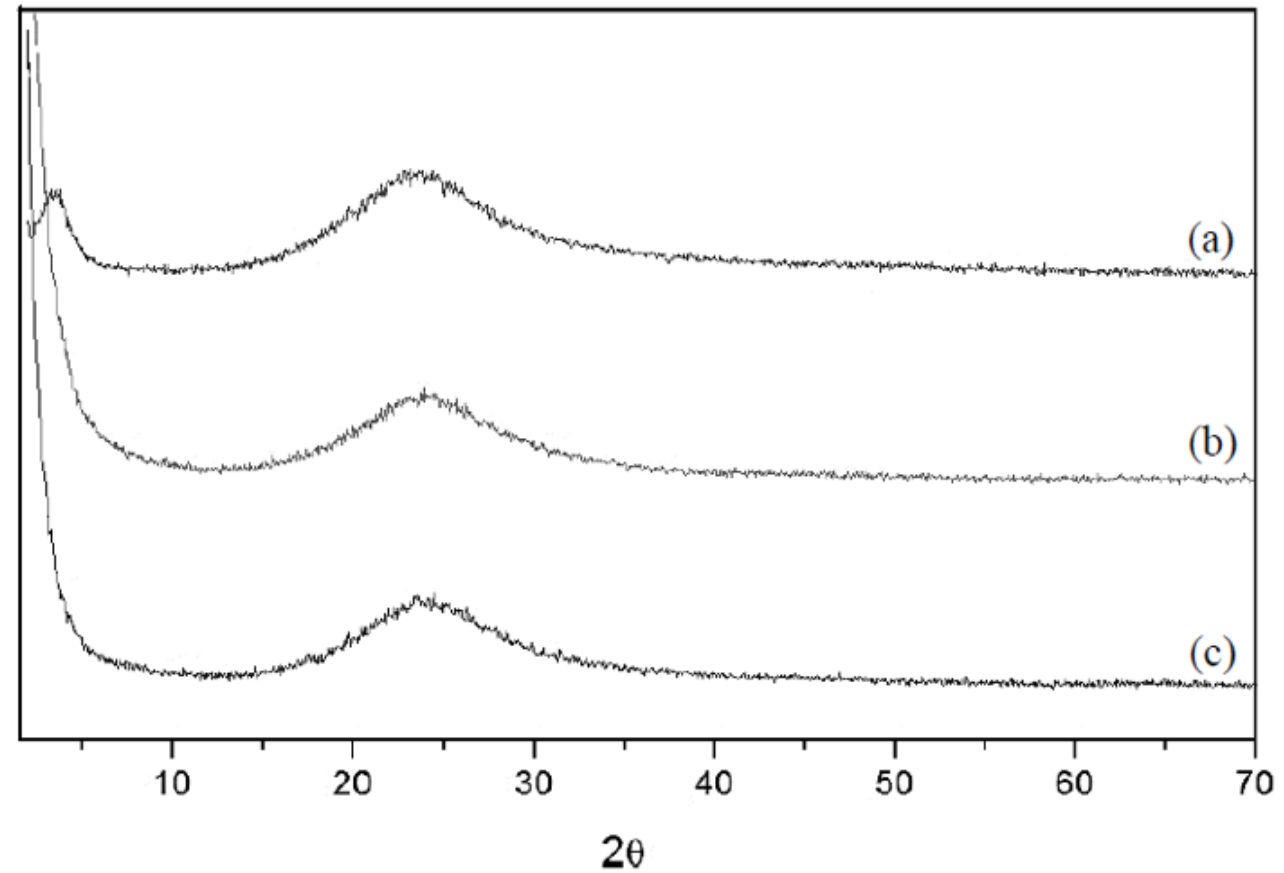

Figure 1. X-ray diffractograms of immobilized aerogels obtained under different drying conditions. (a) 80 bar and $40^{\circ} \mathrm{C}$, (b) 140 bar and $40^{\circ} \mathrm{C}$, and (c) 200 bar and $25^{\circ} \mathrm{C}$.
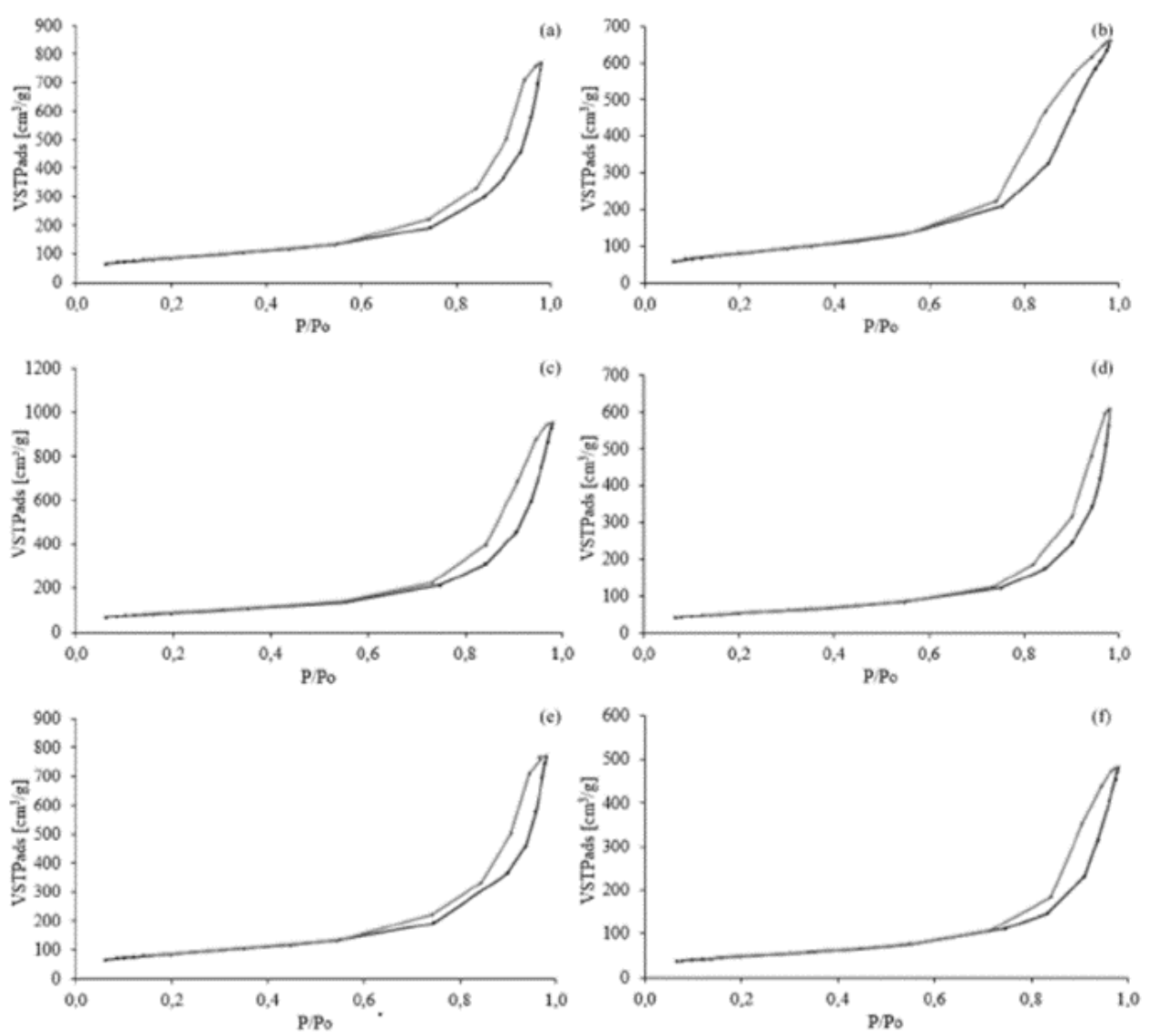

Figure 2. Adsorption-desorption isotherm of silica aerogel. (a) 80 bar and $40{ }^{\circ} \mathrm{C}$ without enzyme, (b) 80 bar and $40{ }^{\circ} \mathrm{C}$ with enzyme, (c) 140 bar and $55^{\circ} \mathrm{C}$ without enzyme, (d) 140 bar and $55^{\circ} \mathrm{C}$ with enzyme, (e) 200 bar and $25^{\circ} \mathrm{C}$ without enzyme and (f) 200 bar and $25^{\circ} \mathrm{C}$ with enzyme. 
The $\mathrm{N}_{2}$ adsorption-desorption isotherms, specific surface area, specific pore volume and diameter of the hydrophobic matrices and immobilized biocatalysts were determined from nitrogen adsorption-desorption measures, which is a method used for the characterization of microporous and mesoporous materials. The textural analysis shows the results in relation to the specific surface area (BET method), pore-volume, and average pore diameter for the solgel matrices and their derivatives [38].

The results of $\mathrm{N}_{2}$ adsorption-desorption textural analyzes performed on aerogel with and without the presence of CALB lipase obtained by different drying conditions are shown in Figure 2.

Aerogels, regardless of the drying condition, presented isotherm type IV, which are characteristically exhibited by mesoporous materials [39], such as silica and $\mathrm{H} 2$ hysteresis type, corresponding to a defined distribution of pore sizes and shapes, with "inkwell" pores, narrow neck and wide body. Aerogels are predominantly mesoporous solids and have low density, mesoporosity, and high surface area [40, 41].

The pore size, surface area, and pore volume distributions of the aerogels determined by the BJH method are shown in Table 1.

Table 1. Morphological characteristics of aerogels.

\begin{tabular}{ccccc}
\hline Aerogel & Drying condition & Surface area $\left(\mathbf{m}^{2} / \mathbf{g}\right)$ & Pore volume $\left(\mathbf{c m}^{3} / \mathbf{g}\right)$ & Pore size $(\AA)$ \\
\hline With enzyme & 80 bar and $40^{\circ} \mathrm{C}$ & 297.41 & 1.01 & 135.35 \\
With enzyme & 140 bar and $55^{\circ} \mathrm{C}$ & 197.83 & 0.90 & 182.25 \\
With enzyme & 200 bar and $25^{\circ} \mathrm{C}$ & 179.70 & 0.73 & 163.12 \\
Without enzyme & $80 \mathrm{bar}$ and $40^{\circ} \mathrm{C}$ & 324.21 & 1.45 & 188.16 \\
Without enzyme & 140 bar and $55^{\circ} \mathrm{C}$ & 312.92 & 1.17 & 186.04 \\
Without enzyme & 200 bar and $25^{\circ} \mathrm{C}$ & 304.66 & 1.10 & 178.11 \\
\hline
\end{tabular}

It is observed for all aerogels, regardless of the drying condition, that the surface area, the volume, and the pore size reduce with the use of the enzyme. This mesoporous structure provides space for the immobilization of the CALB lipase. Also, due to the surface area, this support can facilitate the capture of the substrate and thus assist in increasing the immobilization yield and the activity of the immobilized enzyme [42].

\subsubsection{Thermogravimetric Analysis (TGA).}

The mass loss of the free CALB lipase and the aerogels with and without the enzyme was determined by thermogravimetric analysis and is shown in Figure 3. This technique allows the determination of the temperature range in which the heated samples undergo a conformational change, presenting a mass loss profile.

The value obtained for the mass loss of the aerogel without immobilized lipase was $15.26 \%$, with the largest mass loss observed in the region I (11.25\%). This result may be due to water loss through evaporation that can occur at temperatures up to $200{ }^{\circ} \mathrm{C}$. For the immobilized aerogel, the loss of mass was $74.56 \%$, with the greatest loss of mass also in the region I $(71 \%)$.

It is observed that the aerogel without immobilized lipase presents a lower loss of mass than the aerogel immobilized with lipase. The thermograms were divided into two regions. In Region I, where the temperature is up to $200{ }^{\circ} \mathrm{C}$, weight loss occurs mainly associated with dehydration, decomposition of amino groups, and, generally, organic groups.

In Region II (200 to $600{ }^{\circ} \mathrm{C}$ ), the loss is related with the condensation of silanol groups and the loss of some organic components $(\mathrm{C}, \mathrm{H}, \mathrm{O}$, and $\mathrm{N})$ in the conformation of volatile 
compounds, including lipase and the participation of unreacted silane groups of the precursor TEOS, present in the silica, due to the incomplete sol-gel reaction [43].

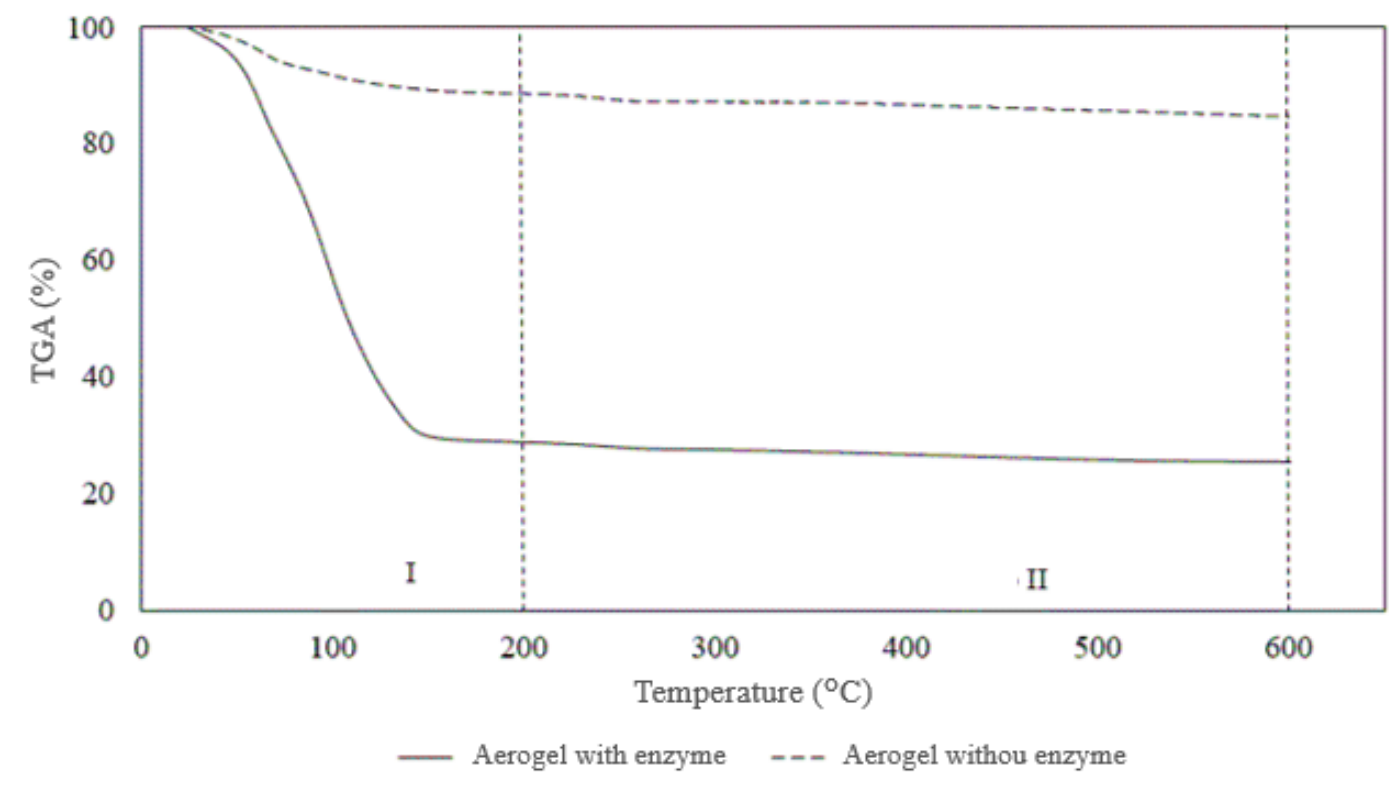

Figure 3. TGA-curves obtained for the aerogels with and without immobilized CALB lipase.

\subsubsection{Scanning electron microscopy (SEM).}

The morphologies of immobilized aerogels obtained under different drying conditions using scanning electron microscopy (SEM) are shown in Figure 4.
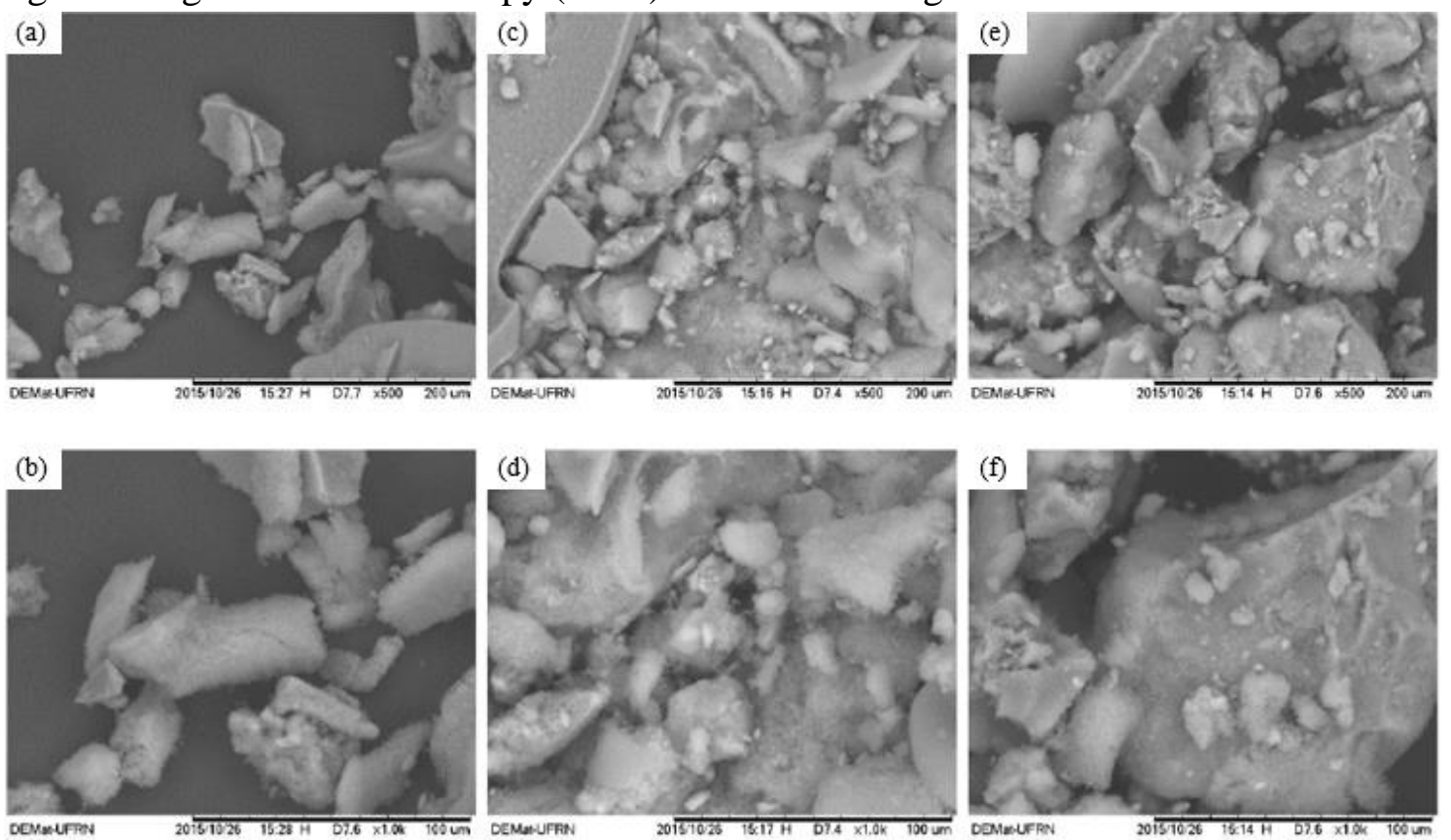

Figure 4. Scanning electron microscopy (SEM) of the aerogel with a magnification of 500 times (a, c, e) and 1000 times $(\mathbf{b}, \mathbf{d}, \mathbf{f})$. (a) and (b) 80 bar and $40{ }^{\circ} \mathrm{C},(\mathbf{c})$ and (d) 140 bar and $55^{\circ} \mathrm{C},(\mathbf{e})$ and (f) 200 bar and $25^{\circ} \mathrm{C}$.

The SEM micrographs of dry aerogel in different conditions show particles with irregular morphologies, without a defined shape, with heterogeneous sizes and less than 200 $\mu \mathrm{m}$. These are typical support structures obtained by the sol-gel technique [44]. Liquid displacement with supercritical carbon dioxide drying avoids surface tension because of the absence of liquid to vapor transition and prevents the microcellular network of the hydrogel from further collapse [45]. 


\subsection{Storage stability.}

Figures $5 \mathrm{a}$ and $5 \mathrm{~b}$ describe the behavior of residual esterification activity for immobilized aerogel, stored at room temperature and refrigeration, respectively.

Regardless of the drying condition, the enzyme immobilized in the aerogel showed a longer storage time when compared to the free enzyme. Regarding the drying condition, the immobilized aerogel showed similar behavior, with an esterification activity greater than $50 \%$ for 165 days of storage at room temperature and greater than 260 days in refrigeration. Among the storage conditions, samples stored in refrigeration showed a performance $60 \%$ higher than that observed for room temperature.
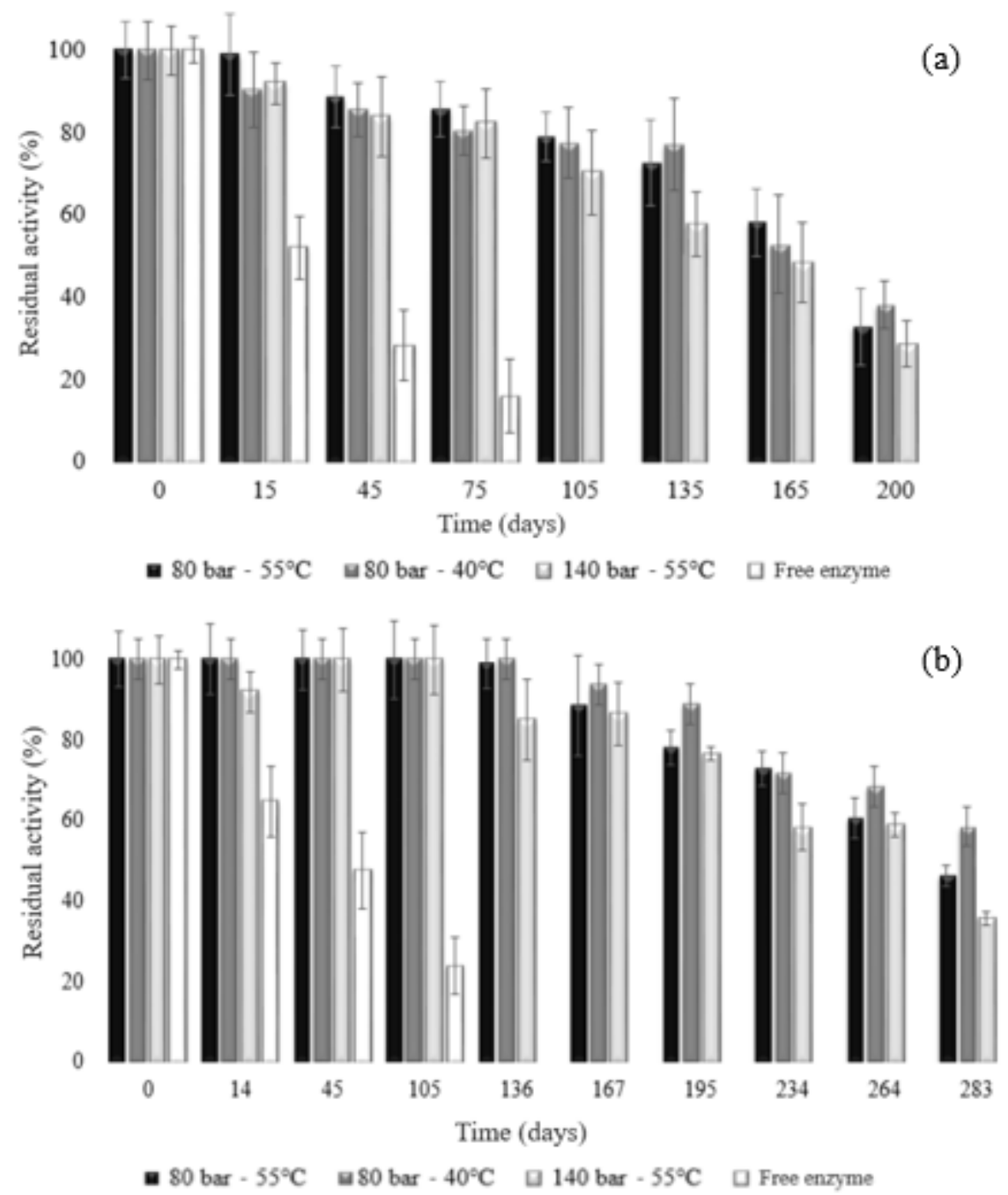

Figure 5. Residual activity in storage stability at room temperature (a) and refrigeration (b) of free and immobilized CALB on silica aerogel under different drying conditions.

Storage stability for long periods is one of the main factors to be considered when using immobilized lipases. These results demonstrate that an important factor is the temperature at which the aerogels are stored.

It is worth mentioning that the results obtained for the storage of aerogel (regardless of the storage method) presented longer times than those described in the literature for xerogels $[46,47]$.

This behavior is linked to the stability provided by the greater porosity of the aerogels, which acts to protect the three-dimensional conformation of the immobilized lipase and the active site from any structural changes that may affect its catalytic activity [48]. 


\subsection{Operational stability.}

The operational stability of the immobilized aerogel was verified in esterification reactions in consecutive batches with the reuse of the immobilized. The results obtained for operational stability are shown in Figure 6.

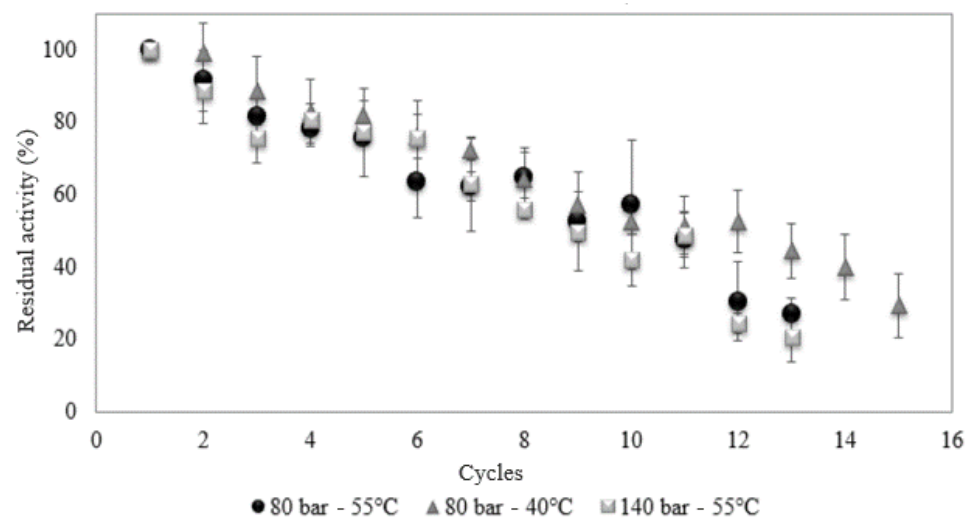

Figure 6. Operational stability of CALB immobilized on silica aerogel in different drying conditions.

The heterogeneous catalyst has received significant interest as it can be reused many times in subsequent cycles without any treatment [49]. All immobilized aerogels showed similar behavior, with a continuous decline in residual activity between cycles, presenting between 8 and 12 cycles with residual activity greater than 50\%. In comparison to the number of cycles obtained, similar results were found in works developed by Maury et al. [50] and Orçaire, Buisson, and Pierre [51]. The authors observed that the catalytic activity of the enzyme decreases to approximately $60 \%$ after 11 cycles.

\subsection{Thermal stability.}

Due to the behavior of the three aerogels for storage and recycling stability, it was decided to achieve thermal stability for the aerogel $\left(80\right.$ bar and $40{ }^{\circ} \mathrm{C}$ ), which showed better results. The stability of free and immobilized lipases was evaluated at temperatures from $40{ }^{\circ} \mathrm{C}$ to $80^{\circ} \mathrm{C}$, with the graphic profile shown in Figure 7.
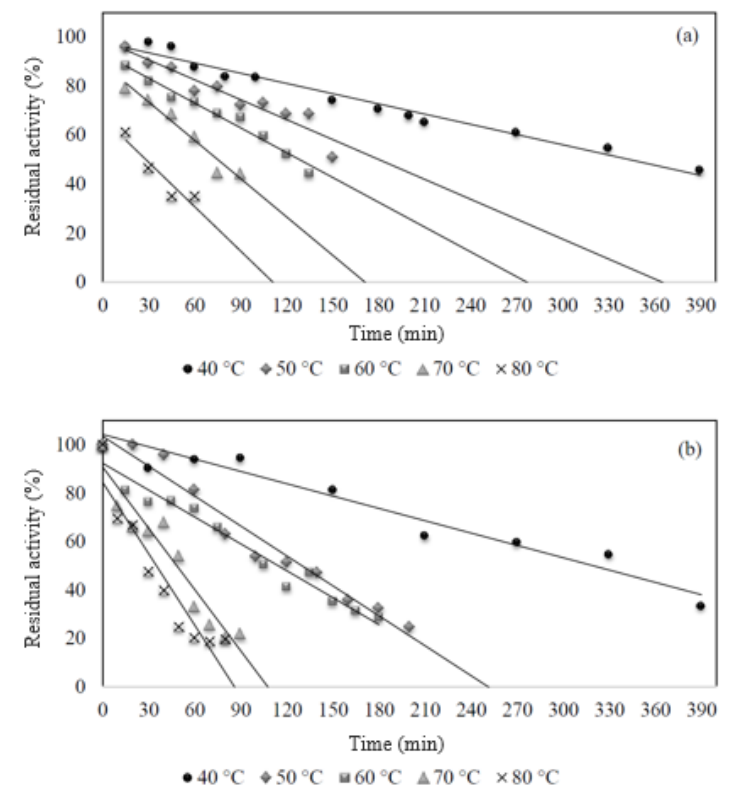

Figure 7. Thermal stability at $40^{\circ} \mathrm{C}, 50^{\circ} \mathrm{C}, 60^{\circ} \mathrm{C}, 70^{\circ} \mathrm{C}$ and $80^{\circ} \mathrm{C}$ of free (a) and immobilized (b) CALB lipase. 
For both lipases (free and immobilized), the lowest loss of activity as a function of time was observed for the lowest temperature employed in this study $\left(40^{\circ} \mathrm{C}\right)$. On the other hand, both lipases showed approximately $20 \%$ of their residual activity in $45 \mathrm{~min}$ of storage at $80{ }^{\circ} \mathrm{C}$. It is also observed that thermal stability varies inversely with temperature.

The values for the thermal deactivation constant and half-life of the free and immobilized CALB lipase in aerogel are shown in Table 2.

Table 2. Thermal deactivation constant $\left(\mathrm{k}_{\mathrm{d}}\right)$, determination coefficients $\left(\mathrm{R}^{2}\right)$, and half-life $\left(\mathrm{t}_{1 / 2}\right)$ of the free and immobilized CALB lipase.

\begin{tabular}{c|ccc|ccc}
\hline \multirow{2}{*}{ Temperature $\left({ }^{\circ} \mathbf{C}\right)$} & \multicolumn{3}{|c|}{ Free enzyme } & \multicolumn{3}{c}{ Immobilized in aerogel } \\
\cline { 2 - 7 } & $\mathbf{k}_{\mathbf{d}}\left(\mathbf{h}^{-\mathbf{1}}\right)$ & $\mathbf{R}^{\mathbf{2}}$ & $\mathbf{t}_{\mathbf{1} / \mathbf{2}}(\mathbf{h})$ & $\mathbf{k}_{\mathbf{d}}\left(\mathbf{h}^{-\mathbf{1}}\right)$ & $\mathbf{R}^{\mathbf{2}}$ & $\mathbf{t}_{\mathbf{1} / \mathbf{2}}(\mathbf{h})$ \\
\hline 40 & 0.12 & 0.89 & 5.79 & 0.12 & 0.93 & 6.02 \\
50 & 0.34 & 0.91 & 2.07 & 0.20 & 0.93 & 3.39 \\
60 & 0.42 & 0.89 & 1.66 & 0.32 & 0.96 & 2.17 \\
70 & 1.06 & 0.94 & 0.65 & 0.57 & 0.95 & 1.21 \\
80 & 1.48 & 0.96 & 0.47 & 1.26 & 0.88 & 0.55 \\
\hline
\end{tabular}

With the exception of the temperature of $40^{\circ} \mathrm{C}$, all other conditions showed lower $\mathrm{k}_{\mathrm{d}}$ values for the immobilized lipase and longer half-lives $\left(t_{1 / 2}\right)$ than those obtained for the free enzyme. Both results suggest that the thermal stability of the immobilized enzyme is greater than that of the free enzyme. In addition, the support in question acts to protect the enzyme from the negative effects of temperature in relation to its active conformation $[52,53]$, enabling its use in processes that require higher temperatures.

The results demonstrated that the immobilization of enzymes, a class of proteins [54], on solid supports is an important tool to enable the use of enzymes, as it allows their reuse and can significantly reduce inactivation due to the influence of temperature and organic solvents. Besides that, an accurate study of characteristics parameters is the most important requirement for many future applications $[55,56]$.

\section{Conclusions}

The immobilization process provided an increase in thermal, storage, and operational stability in relation to the free enzyme. In terms of thermal stability, the aerogel support protected the enzyme from the negative effects of temperature, enabling its use in processes that require higher temperatures. Regarding operational stability, the results demonstrated the possible reuse of immobilized aerogels (between 8 and 12 cycles), proving the efficiency of the method used for immobilization. In addition, regardless of the storage condition, the aerogel had a longer storage time when compared to the free enzyme.

Aerogels, regardless of the drying condition, presented isotherm type IV and amorphous structure. The immobilized aerogel obtained can replace conventional chemical processes in industrial applications due to the good results presented for stability.

\section{Funding}

This research received no external funding.

\section{Acknowledgments}

The authors thank URI-Erechim, National Council for Scientific and Technological Development $(\mathrm{CNPq})$, Coordination for the Improvement of Higher Education Personnel (CAPES), and Research Support Foundation of the State of Rio Grande do Sul (FAPERGS). 


\section{Conflicts of Interest}

\section{The authors declare no conflict of interest.}

\section{References}

1. Basso, A.; Serban, S. Industrial Applications of Immobilized Enzymes-A Review. Mol. Catal. 2019, 479, https://doi.org/10.1016/j.mcat.2019.110607.

2. Ahmad, T.; Aadil, R.M.; Ahmed, H.; Rahman, U.u.; Soares, B.C.V.; Souza, S.L.Q.; Pimentel, T.C.; Scudino, H.; Guimarães, J.T.; Esmerino, E.A.; Freitas, M.Q.; Almada, R.B.; Vendramel, S.M.R.; Silva, M.C.; Cruz, A.G. Treatment and Utilization of Dairy Industrial Waste: A Review. Trends Food Sci. Technol. 2019, 88, 361-372, https://doi.org/10.1016/j.tifs.2019.04.003.

3. Kapoor, M.; Gupta, M.N. Lipase Promiscuity and Its Biochemical Applications. Process Biochem. 2012, 47, 555-569, https://doi.org/10.1016/j.procbio.2012.01.011.

4. Lima, R.T.; Alves, A.M.; de Paula, A.V.; de Castro, H.F.; Andrade, G.S.S. Mycelium-Bound Lipase from Penicillium Citrinum as Biocatalyst for the Hydrolysis of Vegetable Oils. Biocatal. Agric. Biotechnol. 2019, 22, https://doi.org/10.1016/j.bcab.2019.101410.

5. Liu, J.; Ma, R.T.; Shi, Y.P. Recent Advances on Support Materials for Lipase Immobilization and Applicability as Biocatalysts in Inhibitors Screening Methods-A Review. Anal. Chim. Acta 2020, 1101, 922, https://doi.org/10.1016/j.aca.2019.11.073.

6. Guimarães, M.; Pérez-Gregorio, M.; Mateus, N.; de Freitas, V.; Galinha, C.F.; Crespo, J.G.; Portugal, C.A.M.; Cruz, L. An Efficient Method for Anthocyanins Lipophilization Based on Enzyme Retention in Membrane Systems. Food Chem. 2019, 300, https://doi.org/10.1016/j.foodchem.2019.125167.

7. Pazol, J.; Vázquez, A.; Nicolau, E. Characterization of Non-Covalent Immobilized Candida Antartica Lipase b over PS-b-P4VP as a Model Bio-Reactive Porous Interface. Colloids Surfaces B Biointerfaces 2019, 183, https://doi.org/10.1016/j.colsurfb.2019.110418.

8. de Macedo Robert, J.; Garcia-Ortega, X.; Montesinos-Seguí, J.L.; Guimaraes Freire, D.M.; Valero, F. Continuous Operation, a Realistic Alternative to Fed-Batch Fermentation for the Production of Recombinant Lipase B from Candida antarctica under the Constitutive Promoter PGK in Pichia Pastoris. Biochem. Eng. J. 2019, 147, 39-47, https://doi.org/10.1016/j.bej.2019.03.027.

9. Brito e Cunha, D.A.; Bartkevihi, L.; Robert, J.M.; Cipolatti, E.P.; Ferreira, A.T.S.; Oliveira, D.M.P.; GomesNeto, F.; Almeida, R.V.; Fernandez-Lafuente, R.; Freire, D.M.G.; Anobom, C.D. Structural Differences of Commercial and Recombinant Lipase B from Candida antarctica: An Important Implication on Enzymes Thermostability. Int. J. Biol. Macromol., 2019, https://doi.org/10.1016/j.ijbiomac.2019.08.148.

10. Nian, B.; Cao, C.; Liu, Y. Activation and Stabilization of Candida antarctica Lipase B in Choline ChlorideGlycerol-Water Binary System via Tailoring the Hydrogen-Bonding Interaction. Int. J. Biol. Macromol. 2019, 136, 1086-1095, https://doi.org/10.1016/j.ijbiomac.2019.06.150.

11. Zhou, X.; Li, H.; Zheng, L. Directly Covalent Immobilization of Candida antarctica Lipase B on Oxidized Aspen Powder by Introducing Poly-lysines: An Economical Approach to Improve Enzyme Performance. Int. J. Biol. Macromol. 2019, 133, 226-234, https://doi.org/10.1016/j.ijbiomac.2019.04.096.

12. Zhao, X.; Qi, F.; Yuan, C.; Du, W.; Liu, D. Lipase-Catalyzed Process for Biodiesel Production: Enzyme Immobilization, Process Simulation and Optimization. Renew. Sustain. Energy Rev. 2015, 44, 182-197, https://doi.org/10.1016/j.rser.2014.12.021.

13. Forde, J.; Vakurov, A.; Gibson, T.D.; Millner, P.; Whelehan, M.; Marison, I.W.; Ó’Fágáin, C. Chemical Modification and Immobilisation of Lipase B from Candida antarctica onto Mesoporous Silicates. J. Mol. Catal. B Enzym. 2010, 66, 203-209, https://doi.org/10.1016/j.molcatb.2010.05.010.

14. Chen, Y.; Cheong, L.Z.; Zhao, J.; Panpipat, W.; Wang, Z.; Li, Y.; Lu, C.; Zhou, J.; Su, X. Lipase-Catalyzed Selective Enrichment of Omega-3 Polyunsaturated Fatty Acids in Acylglycerols of Cod Liver and Linseed Oils: Modeling the Binding Affinity of Lipases and Fatty Acids. Int. J. Biol. Macromol. 2019, 123, 261268, https://doi.org/10.1016/j.ijbiomac.2018.11.049.

15. Szelwicka, A.; Boncel, S.; Jurczyk, S.; Chrobok, A. Exceptionally Active and Reusable Nanobiocatalyst Comprising Lipase Non-Covalently Immobilized on Multi-Wall Carbon Nanotubes for the Synthesis of Diester Plasticizers. Appl. Catal. A Gen. 2019, 574, 41-47, https://doi.org/10.1016/j.apcata.2019.01.030.

16. Jesionowski, T.; Zdarta, J.; Krajewska, B. Enzyme Immobilization by Adsorption: A Review. Adsorption 2014, 20, 801-821, https://doi.org/10.1007/s10450-014-9623-y.

17. Li, Y.; Wu, J.Q.; Long, N.B.; Zhang, R.F. Efficient Immobilization of Phospholipase D on Novel Polymer Supports with Hierarchical Pore Structures. Int. J. Biol. Macromol. 2019, 141, 60-67, https://doi.org/10.1016/j.ijbiomac.2019.08.192.

18. Chen, M.; Wu, H.; Li, Z.; Wu, K.; Jiao, Y.; Zhou, C. Preparation of Reduced Graphene Oxide Porous Beads for Lipase Immobilization and Its Application for Oil Adsorption and Glycerolysis Reaction in Situ. Microporous Mesoporous Mater. 2020, 294, https://doi.org/10.1016/j.micromeso.2019.109920.

19. Romero-Fernández, M.; Moreno-Perez, S.; Martins de Oliveira, S.; Santamaría, R.I.; Guisan, J.M.; Rocha- 
Martin, J. Preparation of a Robust Immobilized Biocatalyst of $\beta$-1,4-Endoxylanase by Surface Coating with Polymers for Production of Xylooligosaccharides from Different Xylan Sources. N. Biotechnol. 2018, 44, 50-58, https://doi.org/10.1016/j.nbt.2018.04.007.

20. Pereira, A. da S.; Diniz, M.M.; De Jong, G.; Gama Filho, H.S.; dos Anjos, M. .; Finotelli, P.V.; FontesSant'Ana, G.C.; Amaral, P.F.F. Chitosan-Alginate Beads as Encapsulating Agents for Yarrowia Lipolytica Lipase: Morphological, Physico-Chemical and Kinetic Characteristics. Int. J. Biol. Macromol. 2019, 139, 621-630, https://doi.org/10.1016/j.ijbiomac.2019.08.009.

21. Zhong, L.; Feng, Y.; Wang, G.; Wang, Z.; Bilal, M.; Lv, H.; Jia, S.; Cui, J. Production and use of immobilized lipases in/on nanomaterials: A review from the waste to biodiesel production. International Journal of Biological Macromolecules 2020, 152, 207-222, https://doi.org/10.1016/j.ijbiomac.2020.02.258.

22. Mendes, A.A.; Rodrigues, D.S.; Filice, M.; Fernandez-Lafuente, R.; Guisan, J.M.; Palomo, J.M. Regioselective Monohydrolysis of Per-O-Acetylated-1-Substituted- $\beta$-Glucopyranosides Catalyzed by Immobilized Lipases. Tetrahedron 2008, 64, 10721-10727, https://doi.org/10.1016/j.tet.2008.08.099.

23. Kato, K.; Nakagaki, S.; Nishida, M.; Hirao, K. Enzyme Encapsulation in Silica Particles Prepared Using Enzyme-Assisted Sol-Gel Reactions in Ionic Liquids. J. Ceram. Soc. Japan 2011, 119, 140-143, https://doi.org/10.2109/jcersj2.119.140.

24. Rodrigues, R.C.; Virgen-Ortíz, J.J.; dos Santos, J.C.S.; Berenguer-Murcia, Á.; Alcantara, A.R.; Barbosa, O.; Ortiz, C.; Fernandez-Lafuente, R. Immobilization of Lipases on Hydrophobic Supports: Immobilization Mechanism, Advantages, Problems, and Solutions. Biotechnol. Adv. 2019, 37, 746-770, https://doi.org/10.1016/j.biotechadv.2019.04.003.

25. Abdel-Naby, M.A.; Fouad, A.; Reyad, R.M. Catalytic and Thermodynamic Properties of Immobilized Bacillus Amyloliquefaciens Cyclodextrin Glucosyltransferase on Different Carriers. J. Mol. Catal. B Enzym. 2015, 116, 140-147, https://doi.org/10.1016/j.molcatb.2015.03.011.

26. Angelova, T.; Rangelova, N.; Georgieva, N.; Nemska, V.; Stoyanova, T.; Uzunova, V.; Aleksandrov, L.; Tzoneva, R. Study of Potential Biomedical Application of Sol-Gel Derived Zn-Doped SiO 2 -Hydroxypropyl Cellulose Nanohybrids. Mater. Sci. Eng. C 2019, 100, 608-615, https://doi.org/10.1016/j.msec.2019.03.018.

27. Benvenuti, J.; Fisch, A.; Dos Santos, J.H.Z.; Gutterres, M. Silica-Based Adsorbent Material with Grape Bagasse Encapsulated by the Sol-Gel Method for the Adsorption of Basic Blue 41 Dye. J. Environ. Chem. Eng. 2019, 7, https://doi.org/10.1016/j.jece.2019.103342.

28. Milea, C.A.; Bogatu, C.; Duta, A. The Influence of Parameters in Silica Sol-Gel Process. Eng. Sci. 2011, 4, 59-66.

29. Yue, X.; Zhang, T.; Yang, D.; Qiu, F.; Li, Z. Hybrid Aerogels Derived from Banana Peel and Waste Paper for Efficient Oil Absorption and Emulsion Separation. J. Clean. Prod. 2018, 199, 411-419, https://doi.org/10.1016/j.jclepro.2018.07.181.

30. Lisboa, M.C.; Rodrigues, C.A.; Barbosa, A.S.; Mattedi, S.; Freitas, L.S.; Mendes, A.A. New Perspectives on the Modification of Silica Aerogel Particles with Ionic Liquid Used in Lipase Immobilization with Platform in Ethyl Esters Production. Process Biochem. 2018, 75, 157-165, https://doi.org/10.1016/j.procbio.2018.09.015.

31. Soares, C.M.F.; Dos Santos, O.A.; De Castro, H.F.; De Moraes, F.F.; Zanin, G.M. Studies on Immobilized Lipase in Hydrophobic Sol-Gel. Appl. Biochem. Biotechnol. - Part A Enzym. Eng. Biotechnol. 2004, 113, 307-319, https://doi.org/10.1385/ABAB:113:1-3:307.

32. Nassreddine, S.; Karout, A.; Lorraine Christ, M.; Pierre, A.C. Transesterification of a Vegetal Oil with Methanol Catalyzed by a Silica Fibre Reinforced Aerogel Encapsulated Lipase. Appl. Catal. A Gen. 2008, 344, 70-77, https://doi.org/10.1016/j.apcata.2008.04.002.

33. Barbosa, A.S.; Lisboa, J.A.; Silva, M.A.O.; Carvalho, N.B.; Pereira, M.M.; Fricks, A.T.; Mattedi, S.; Lima, Á.S.; Franceschi, E.; Soares, C.M.F. The Novel Mesoporous Silica Aerogel Modified with Protic Ionic Liquid for Lipase Immobilization. Quim. Nova 2016, 39, 415-422, https://doi.org/10.5935/01004042.20160042.

34. Ficanha, A.M.M.; Antunes, A.; Oro, C.E.D.; Valduga, A.T.; Matuella Moreira, C.; Dallago, R.M.; Mignoni, M. Study of Drying Conditions of the Aerogel Obtained by the Sol-Gel Technique for Immobilization in Situ of Lipase Candida antarctica B. Ind. Biotechnol. 2019, 15, 350-356, https://doi.org/10.1089/ind.2019.0003.

35. Ficanha, A.M.M.; Nyari, N.L.D.; Levandoski, K.; Mignoni, M.L.; Dallago, R.M. Study of Immobilization of Lipase in Silica by the Sol-Gel Technique. Quim. Nova 2015, 38, 364-369, https://doi.org/10.5935/01004042.20150027.

36. Brunauer, S.; Emmett, P.H.; Teller, E. Adsorption of Gases in Multimolecular Layers. J. Am. Chem. Soc. 1938, 60, 309-319, https://doi.org/10.1021/ja01269a023.

37. Hench, L.L.; Noguès, J.L. Sol-Gel Processing of Net Shape Silica Optics. Sol-Gel Opt. 1994, 59-81, https://doi.org/10.1007/978-1-4615-2750-3_3.

38. Souza, R.L.; Resende, W.C.; Barão, C.E.; Zanin, G.M.; de Castro, H.F.; Santos, O.A.A.; Fricks, A.T.; Figueiredo, R.T.; Lima, Á.S.; Soares, C.M.F. Influence of the use of Aliquat 336 in the immobilization procedure in sol-gel of lipase from Bacillus sp. ITP-001. Journal of Molecular Catalysis B: Enzymatic 2012, 84, 152-159, https://doi.org/10.1016/j.molcatb.2012.05.013. 
39. Gregg, S.J.; Sing, K.S.W. Adsorption, Surface Area and Porosity. 2nd ed.; Auflage, Academic Press: London, 1982.

40. Hüsing, N.; Schubert, U. Aerogels-Airy Materials: Chemistry, Structure, and Properties. Angew. Chemie Int. Ed., 1998, 37, 22-45, https://doi.org/10.1002/(SICI)1521-3773(19980202)37:1/2<22::AIDANIE22>3.0.CO;2-I.

41. Cuce, E.; Cuce, P.M.; Wood, C.J.; Riffat, S.B. Toward Aerogel Based Thermal Superinsulation in Buildings: A Comprehensive Review. Renew. Sustain. Energy Rev. 2014, 34, 273-299, https://doi.org/10.1016/j.rser.2014.03.017.

42. Zhang, Y.; Ge, J.; Liu, Z. Enhanced Activity of Immobilized or Chemically Modified Enzymes. ACS Catal. 2015, 5, 4503-4513, https://doi.org/10.1021/acscatal.5b00996.

43. Mukherjee, I.; Mylonakis, A.; Guo, Y.; Samuel, S.P.; Li, S.; Wei, R.Y.; Kojtari, A.; Wei, Y. Effect of Nonsurfactant Template Content on the Particle Size and Surface Area of Monodisperse Mesoporous Silica Nanospheres. Microporous Mesoporous Mater. 2009, 122, 168-174, https://doi.org/10.1016/j.micromeso.2009.02.030.

44. Tewari, P.H.; Hunt, A.J.; Lofftus, K.D. Ambient-Temperature Supercritical Drying of Transparent Silica Aerogels. Mater. Lett. 1985, 3, 0-4, https://doi.org/10.1016/0167-577X(85)90077-1.

45. Tsai, W.; Wang, Y. Progress of Supercritical Fluid Technology in Polymerization and Its Applications in Biomedical Engineering. Prog. Polym. Sci. 2019, 98, https://doi.org/10.1016/j.progpolymsci.2019.101161.

46. Soares, C.M.F.; dos Santos, O.A.; de Castro, H.F.; de Moraes, F.F.; Zanin, G.M. Characterization of SolGel Encapsulated Lipase Using Tetraethoxysilane as Precursor. J. Mol. Catal. B Enzym. 2006, 39, 69-76, https://doi.org/10.1016/j.molcatb.2006.01.005.

47. Yilmaz, E.; Sezgin, M.; Yilmaz, M. Immobilization of Candida Rugosa Lipase on Magnetic Sol-Gel Composite Supports for Enzymatic Resolution of (R,S)-Naproxen Methyl Ester. J. Mol. Catal. B Enzym. 2011, 69, 35-41, https://doi.org/10.1016/j.molcatb.2010.12.007.

48. Kharrat, N.; Ali, Y. Ben; Marzouk, S.; Gargouri, Y.T.; Karra-Châabouni, M. Immobilization of Rhizopus Oryzae Lipase on Silica Aerogels by Adsorption: Comparison with the Free Enzyme. Process Biochem. 2011, 46, 1083-1089, https://doi.org/10.1016/j.procbio.2011.01.029.

49. Dhawane, S.H.; Kumar, T.; Halder, G. Recent Advancement and Prospective of Heterogeneous Carbonaceous Catalysts in Chemical and Enzymatic Transformation of Biodiesel. Energy Convers. Manag. 2018, 167, 176-202, https://doi.org/10.1016/j.enconman.2018.04.073.

50. Maury, S.; Buisson, P.; Perrard, A.; Pierre, A.C. Compared Esterification Kinetics of the Lipase from Burkholderia Cepacia Either Free or Encapsulated in a Silica Aerogel. J. Mol. Catal. B Enzym. 2005, 32, 193-203, https://doi.org/10.1016/j.molcatb.2004.12.006.

51. Orçaire, O.; Buisson, P.; Pierre, A.C. Application of Silica Aerogel Encapsulated Lipases in the Synthesis of Biodiesel by Transesterification Reactions. J. Mol. Catal. B Enzym. 2006, 42, 106-113, https://doi.org/10.1016/j.molcatb.2006.08.002.

52. Yang, G.; Wu, J.; Xu, G.; Yang, L. Comparative Study of Properties of Immobilized Lipase onto Glutaraldehyde-Activated Amino-Silica Gel via Different Methods. Colloids Surfaces B Biointerfaces 2010, 78, 351-356, https://doi.org/10.1016/j.colsurfb.2010.03.022.

53. Zubiolo, C.; Santos, R.C.A.; Carvalho, N.B.; Soares, C.M.F.; Lima, A.S.; De Aquino Santana, L.C.L. Encapsulation in a Sol-Gel Matrix of Lipase from Aspergillus Niger Obtained by Bioconversion of a Novel Agricultural Residue. Bioprocess Biosyst. Eng. 2014, 37, 1781-1788, https://doi.org/10.1007/s00449-0141151-3.

54. Diaa, A.; Abd Elaziz, M.; Ahmed, F. Protein Structure from the Essential Amino Acids to the 3D structure. Biointerface Res. Appl. Chem., 2019, 9 (1), 3817-3824. https://doi.org/10.33263/BRIAC91.817824

55. Emadi, H.; Mobarak, H. Synthesis and Characterization of Copper Ferrite Nanoparticles and Its Application as MRI Contrast Agent. Lett. Appl. NanoBioScience, 2019, 8 (1), 541-544. https://doi.org/10.33263/LIANBS81.541544.

56. Farrage, N. M.; Oraby, A. H.; Abdelrazek, E. M. M.; Atta, D. Synthesis, Characterization of Ag@PANI Core-Shell Nanostructures Using Solid State Polymerization Method. Biointerface Res. Appl. Chem., 2019, 9 (3), 3934-3941. https://doi.org/10.33263/BRIAC93.934941. 